\title{
A CASE REPORT ON ILD-NSIP, PULMONARY ARTERIAL HYPERTENSION IN ASSOCIATION WITH SJOGRENS'S SYNDROME
}

\begin{tabular}{ll}
\hline Pharmacy & \\
$\begin{array}{ll}\text { Shivani Singh } \\
\text { Thakur* }\end{array}$ & $\begin{array}{l}\text { Pulla Reddy Institute Of Pharmacy Dommadugu (vil), Gummadidala (mdl), Sangareddy } \\
\text { (dist), Telangana, India.*Corresponding Author }\end{array}$ \\
\hline Chittipolu Shirisha & $\begin{array}{l}\text { Pulla Reddy Institute Of Pharmacy Dommadugu (vil), Gummadidala (mdl), Sangareddy } \\
\text { (dist), Telangana, India }\end{array}$ \\
\hline
\end{tabular}

\section{ABSTRACT}

Sjogren syndrome with various pulmonary symptoms and the common manifestations are diffuse parenchymal lung disease and tracheobronchial disease. Association with ILD-NSID, pulmonary embolism, pulmonary hypertension are rare. We experienced a case of ILD-NSIP accompanied with sjogren's syndrome and are treated further and we present the details of the case here in.

\section{KEYWORDS}

Sjogrens syndrome, interstitial lung disease, non specific interstitial pneumonia, pulmonary arterial hypertension.

\section{INTRODUCTION:}

Primary sjogren syndrome (ss) was originally described in 1926 by Gougerot $^{(1)}$. It is a multisystem autoimmune disease characterized by a triad of symptoms such as xerostomia, xerophthalmia, and polyarthritis ${ }^{2)}$. It can occur as primary disorder or as a secondary condition such as rheumatoid arthritis, systemic lupus erythematous and scleroderma $a^{(3)}$

The primary SS patients may develop pulmonary abnormalities such as interstitial lung disease (ILD), airway lymphoma, pseudo lymphoma, pulmonary vascularitis, and granulomatous disease. They may also develop the whole spectrum of lymphoproliferative disorders of the lung ${ }^{(4,5,6)}$.

ILD-NSIP (non specific interstitial pneumonia) is an idiopathic interstitial pneumonia that occurs mostly in women between the ages 40 and 50. Patients have cough and dyspnea which can be present for months to years. Diagnosis which may have high resolution CT and lung biopsy

Pulmonary arterial hypertension (PAH) is characterized by increased right ventricular pressure and pulmonary resistance. It may result in cardiac failure, pedal edema, arrhythmia, death ${ }^{(8)}$

\section{CASE REPORT:}

A 49yrs old female patient presented with complaints of dyspnea, shortness of breath on minimal exertion since 2months. She was evaluated outside and diagnosed as severe PAH and got here for further management.

Physical examination revealed a temperature of $98.6^{\circ} \mathrm{F}$, Oxygen saturation of $94 \%$ at RA and $98 \%$ with 2 lts $O 2, B P$ of $150 / 100 \mathrm{mmHg}$, pulse rate of $100 \mathrm{bpm}, \mathrm{CVS}-\mathrm{S} 1 \mathrm{~S} 2+, \mathrm{RR}-\mathrm{BAE}+$ with basal crepts + and $P / A$ was found to be soft. Further examination revealed ESR of $28 \mathrm{~mm} / \mathrm{hr}(1 \mathrm{st} \mathrm{hr})$ and $58 \mathrm{~mm} / \mathrm{hr}(2 \mathrm{nd} \mathrm{hr})$.

Laboratory results showed increase in serum chloride level$110 \mathrm{mmol} / \mathrm{L}$ (95-105mmol/L). RBS- $132 \mathrm{mg} / \mathrm{dl}(80-130 \mathrm{mg} / \mathrm{dl})$, serum urea of $58 \mathrm{mg} / \mathrm{dl}$ (5-20md/dl). Chest X-ray showed known clo ILD, ground glass opacities in bilateral lower zones.

High chest radiography revealed subpleural reticular interstitial thickening, ground glassing and mild traction bronchietasis in both lungs with basal predominance and immediate subpleural sparing in bilateral basal segments. Features suggest ILD-NSIP pattern, mediastinal lymhadenopathy, dilatedpulmonary trunk with cardiomegaly and pericardial effusion- to correlate with ECHO to rule out PAH. $2 D$ ECHO s/o RA, RV dilated, D-shaped LV, no LV RWMA, normal LV systolic function, Grade-1 diastolic dysfunction, $R V$ dysfunction- TAPSE-1.7cm, mild MR/no AR/moderate TR/ severe $P A H$, no LA/LV/Clot/ minimal pericardial effusion. Anti RO 52 ANA+ve.

Based on clinical features and investigation the patient was diagnosed as Sjogren's syndrome with ILD-NSIP, DCMP with LV dysfunction.

\section{DISCUSSION:}

In $9-20 \%$ of cases is associated with various respiratory symptoms (9). Airway involvement is common and is manifested by cough. It may affect trachea, bronchi, bronchioles and abnormalities on CT include bronchiectasis. Patient has bronchietasis and with a low frequency anti-RO antibody+ve. HRCT is considered in detection of bronchiectasis ${ }^{(10)}$. Standard treatment for ILD-NSIP is with corticosteroids and sometimes immunosuppressive drugs and for PAH is the use of endothelin receptor antagonist, Phosphodiesterase type-5 inhibitors; while in case of treatment failure first line immunosuppressants are added

Occurrence of PAH is rare in SS. During the hospital stay the patient was treated with inhalation, IV antibiotics, PPI's, nebulisation, IV steroids, DMARDS, Analgesic, antipyretics, anticoagulants, diuretics, statins, inotropes, IV fluids and other supportive care was given. Vaccination of influenza and pneumococcal was given to the patient. Patient was symptomatically improved and been discharged.

\section{CONCLUSION:}

ILD-NSIP is a rare manifestation in patients with SS. Similarly PAH is a rare manifestation in SS. It is unusual to get both conditions together in case of SS. There is a considerable clinical heterogenicity and one or other manifestation can predominate or can be only expression of this syndrome. Timely diagnosis, early treatment and a multidisciplinary approach are vital for optimal case of the patient.

\section{ACKNOWLEDGEMENT:}

The authors are thankful for the Pulla Reddy Institute of Pharmacy, Management and hospital for providing necessary facilities to carry out the case report.

\section{REFERENCE:}

Gougerot $H$. Insuffisance progressive et atrophie des glandes salivaires et muqueuses de la bouche des conjonctives (et parfois des muqueuses nasale laryngee, vulvaire): secheresse"de la bouche, des conjonctives, etc. Bull Soc Franc Derm Syph. 1925;32:376-9.

2. Khandelwal D, Bhattacharya S, Gadodia A, Khadgawat R, Tandon N, Ammini AC Metabolic bone disease as a presenting manifestation of primary Sjögren's syndrome: Three cases and review of literature. Indian J Endocrinol Metab. 2011 Oct 1;15(4):341-

3. Bowman SJ, Ibrahim GH, Holmes G, Hamburger J, Ainsworth JR. Estimating the prevalence among Caucasian women of primary Sjögren's syndrome in two general practices in Birmingham, UK. Scandinavian journal of rheumatology. 2004 Jan practices in Birmi

4. Pralay K. Sarkarl, Nick Patell, Richard A. Furie, Arunabh Talwar Pulmonary Manifestations of primary sjogren's syndrome. The Indian Journal of Chest Disease and Allied Sciences 2009; 51:93-100.

Hwang JA, Yang TH, Lee JY, Koo DW, Choi IS, Cho SY, Kim MS. Severe pulmonary hypertension in primary Sjögren's syndrome. Korean circulation journal. 2013 Jul 1;43(7):504-7.

6. Hedgpeth MT, Boulware DW. Pulmonary hypertension in primary Sjögren's syndrome. Annals of the rheumatic diseases. 1988 Mar 1;47(3):25l-3.

Kligerman SJ Groshong $S$, Brown KK, Lynch DA. Nonspecific interstitial pneumonia: radiologic, clinical, and pathologic considerations. Radiographics. 2009 pneumonia. radiolog

Hatano S. Strasser T. World Health Organization 1975 primary pulmonary Hatano $S$, Strat
hypertension.

hypertension.
Flament T, Bigot A, Chaigne B, Henique H, Diot E, Marchand-Adam S. Pulmonary manifestations of Sjögren's syndrome. European Respiratory Review. 2016 Jun $1 ; 25(140): 110-23$

10. Nannini C, Jebakumar AJ, Crowson CS, Ryu JH, Matteson EL. Primary Sjögren's 
syndrome 1976-2005 and associated interstitial lung disease: a population-based study of incidence and mortality. BMJ open. 2013 Nov 1:3(11):e003569.

11. Fuster V, Steele PM, Edwards WD, Gersh BJ, McGoon MD, Frye RL. Primary

pulmonary hypertension: natural history and the importance of thrombosis. Circulation. 1984 Oct; 70(4):580-7. 